\title{
Resilience among Undergraduate Medical Students of a Medical College of Eastern India
}

\author{
Archan Mukherjee ${ }^{1}$, Tapas Kumar Som ${ }^{2}$, Sudip Ghosh ${ }^{3}$, Riya Mondal ${ }^{4}$, Indranil Saha ${ }^{5}$, Gautam Ghose ${ }^{6}$ \\ ${ }^{1}$ Tutor. Community Medicine, IQ City Medical College, Durgapur, West Bengal.India; ${ }^{2}$ Assistant Professor.Community \\ Medicine, IQ City Medical College, Durgapur, West Bengal.India; ${ }^{3}$ Assistant Professor (Biostatistics).Community Medicine, IQ \\ City Medical College, Durgapur, West Bengal.India; ${ }^{4}$ Post graduate trainee, Department of Community Medicine, IQ City \\ Medical College, Durgapur, West Bengal.India; ${ }^{5}$ Professor \& HOD, Community Medicine, IQ City Medical College, Durgapur, \\ West Bengal.India; ${ }^{6}$ Principal\&Professor.Community Medicine, IQ City Medical College, Durgapur, West Bengal. India.
}

\begin{abstract}
Background: Resilience is a dynamic capability which helps people to survive on challenges given appropriate social and personal contexts. Objective: To determine the resilience and to find out the association between resilience and selected socio-demographic variables, if any. Methodology: An institution based mixed method study was conducted among MBBS students from April to May, 2018 at IQ City Medical College by using Child and Youth Resilience Measures Questionnaire (CYRM-28). Multivariate analysis of variance (MANOVA) was performed using SPSS-21software.Results: Older students, Males, $8^{\text {th }}$ semester batch, and day boarder were more resilient in certain areas. In individual and contextual domain, score gradually increased with increase in age groups. Resilience score were more or less similar among both the sexes. $8^{\text {th }}$ semester students were found to be more resilient in all the domains. Personal skills, social skills, psychological care giving, education, played much larger role in differences across the sex, age, semester, and accommodation. Conclusion:Thus counselling and more teacher student bonding are required to propagate the resilience of the medical students. More emphasis has to be given on identified areas so as to make our future doctors more strong and resilient. KEYWORDS
\end{abstract}

Resilience, MBBS Students, Medical Students, CYRM

\section{INTRODUCTION}

Symptoms of anxiety and depression are quite common among medical students. Severity of symptoms of anxiety and symptoms of depression in medical students is negatively related to emotional stability and positively related to stress vulnerability. ${ }^{[1]}$ That means the students who are emotionally stable are less vulnerable to depression or anxiety and on other hand the students who are having less stress are less prone to become a victim of depression or anxiety. In different studies it was found that a higher level of perceived stress was reported by the students. The main causes of stress were related to academic and psychosocial spheres. ${ }^{[2,3]}$ Medical students were found to be satisfied during the first year, but as the years progress satisfaction level came down and the satisfaction level was found to be least at their graduation year. Medical students with high levels of life satisfaction perceived medical school as less interfering with their social and personal life than their colleagues ${ }^{[4]}$.

Resilience is "the capacity of a system to absorb disturbance and reorganize while undergoing change so as to still retain essentially the same function, structure, identity, and feedbacks" [5]. Resilience thought process focuses on three areas of social-ecological systems (SES): resilience as persistence, adaptability and transformability. Resilience is the tendency to change to remain subject of a SES within a stability domain, continually changing and adapting yet remaining within critical thresholds. More over adaptability is a part of resilience. Adaptability is the capacity of a SES to adjust its responses to changing external drivers and internal processes and thereby allow for

CORRESPONDING AUTHOR: Dr. Tapas Kumar Som, MD Community Medicine. Assistant Professor. Community Medicine, IQ City Medical College. Durgapur. West Bengal, India

E Mail ID: tapas.som@iqct.in

ARTICLE CYCLE: Received: 25/05/2021; Revised: 14/06/2021; Accepted: 22/06/2021; Published:30/06/2021

CITATION: Mukherjee A, Som TK, Ghosh S, Mandal R, Saha I, Ghose G.Resilience among Undergraduate Medical

Students of a Medical College of Eastern India.J Comp Health. 2021;9(1):18-22. 
development within the current stability domain, along the current trajectory [6]. Furthermore, stable high levels of life satisfaction in medical school corresponded to low levels of stress in the form of one's perception of social and personal renunciations, and by low levels of wishful thinking as a way of coping ${ }^{[7]}$.

Nowadays, resilience has utmost importance in terms of coping strategy, which will help the students to balance between stressors and normal life. Many inadvertent events like suicide, drug addiction etc. can be averted among the students who are having a reasonable resilience. With this background the present study was conducted with the objective to determine the resilience and to find out association between resilience and selected socio-demographic variables, if any, among undergraduate medical students of a medical college of eastern India.

\section{MATERIAL \& Methods}

The present study was a mixed method design conducted at IQ City Medical College from April to May, 2018, situated in Durgapur district, West Bengal. In preparing questionnaire, qualitative method was employed and then with the final questionnaire quantitative method was applied (exploratory sequential mixed method design). The study population comprised of MBBS students of $4^{\text {th }}, 6^{\text {th }}$, and $8^{\text {th }}$ semester batches. The students who had experienced the rigors of medical schooling for at least one year were included in the study. As first year students had only 5 months of exposure of medical schooling, so they were not considered as study population. Students who did not give written consent were excluded from the study. All the students from these batches were approached for the study, thus complete enumeration method was followed and finally 242 study participants could be covered with a response rate of $86 \%$.

A predesigned and pretested questionnaire, which also included Child and Youth Resilience Measures Questionnaire (CYRM-28) was used as a study tool. This CYRM-28 questionnaire was developed by Resilience Research Centre. Permission was taken from Resilience Research Centre, Michael Ungar, School of Social Work, Dalhousie University, Halifax, Nova Scotia, CANADA, ResilienceResearch.org to use in the present study. This questionnaire is made up of five pointlikert Scale which ranged from not at all (1), a little (2), some-what (3), quite a bit (4), and a lot (5) ${ }^{[8]}$. This CYRM questionnaire had three sections - Section A contains Socio- demographic characteristics, Section B contains site specific questions and Section $C$ contains specific CYRM 28 questions. In section $A$, socioeconomic status of the participants was assessed by modified BG Prasad scale.

For construction of questions for the Section B, one focus group discussion (FGD) was conducted with the study subjects as recommended by Resilience Research Centre. Altogether 9 students, 3 students from each three semesters from the same college participated in the FGD. One faculty member moderated the sessions and another faculty member took the field note. A group of faculty members of the department of Community Medicine reviewed the focus group data and 10 relevant questions that have emerged from the discussion were taken into consideration for site specific questions for section $B$.

In Section C, there were total 28 questions. These 28 questions are broadly divided into three categories, questions indicating caregiver, contextual, and individual resilience skill. Again, individual resilience skill section is further sub divided into personal skills, peer support, and social skills. The caregiver section is further sub divided into the two sections like physical caregiving and psychological caregiving. Contextual section is sub divided into spiritual, education, and cultural sections. Thus the entire section $\mathrm{C}$ has 8 different outcomes.

Data were collected by approaching study participants at the end of their lecture class and the questionnaire was distributed among them after explaining about the purpose of the study. The study was initiated after getting approval from Institutional Ethics Committee. Confidentiality and anonymity was maintained during the entire study period.

Collected data were entered into a Microsoft Excel worksheet (Microsoft, Redwoods, WA, USA). Categorical data were expressed in proportions. At first continuous data was checked for normality distribution and the scores were found to be normally distributed as evident from non significant $P$ value of Kolmogarov Smirnov test. Thus continuous data were expressed in mean, and standard deviation. A multivariate analysis of variance (MANOVA) was performed by taking sex, age, semester batches and accommodation as independent variables and the eight groupings of CYRM-28 questions as the dependent variables. All the analysis was performed by using SPSS software (Statistical 
Package for the Social Sciences Inc., Chicago, IL, USA), version 21.0 and $P$ value equal to or less than 0.05 was considered as statistically significant.

\section{RESULTS}

Out of 242 students, $4^{\text {th }}, 6^{\text {th }}$ and $8^{\text {th }}$ semester students were $29.7 \%, 36 \%$ and $34.7 \%$ respectively. Participation from $4^{\text {th }}$ semester students was less due to the ongoing supplementary examination at that time. Mean age of the students was found to be 21.3 years with a range from $18-23$ years. With a malefemale ratio almost equal, most of the participants were Hindu (86.7\%), from urban area $(95.6 \%)$, day boarder (69\%) and from class I (upper higher) socio-economic status (99.2\%). Regarding the course curriculum, whether it is hectic or not, resilience score gradually increased with increase in age groups. Males, $8^{\text {th }}$ semester students, and day boarder were more resilient in this area. Junior batch, male students opined for availability of counseling sessions at the institute as they had low resilience scores. Again, junior most batches, males and younger age group opined the difficulty in English medium of teaching, as evident from lower resilience scores among them. Almost all the students were more or less happy in studying inside the college campus (Table 1).

Table 1: Distribution of Resilience Score on the basis of age, sex, semesters,accommodations according to FGD questionnaire

\begin{tabular}{|c|c|c|c|c|c|c|c|c|c|c|}
\hline \multirow[t]{3}{*}{ Parameters } & \multicolumn{3}{|c|}{ Age (years) } & \multicolumn{2}{|c|}{ Sex } & \multicolumn{3}{|c|}{ Semester } & \multicolumn{2}{|c|}{ Accommodation } \\
\hline & $18-19$ & $20-21$ & $22-23$ & $\mathbf{M}$ & $\mathbf{F}$ & 4th & 6th & 8th & Hostelite & $\begin{array}{l}\text { Day } \\
\text { Boarder }\end{array}$ \\
\hline & $\begin{array}{l}\text { Mean } \\
\text { ( SD) }\end{array}$ & $\begin{array}{l}\text { Mean } \\
\text { (SD) }\end{array}$ & $\begin{array}{l}\text { Mean } \\
\text { (SD) }\end{array}$ & $\begin{array}{l}\text { Mean } \\
\text { (SD) }\end{array}$ & $\begin{array}{l}\text { Mean } \\
\text { (SD) }\end{array}$ & $\begin{array}{l}\text { Mean } \\
\text { (SD) }\end{array}$ & $\begin{array}{l}\text { Mean } \\
\text { (SD) }\end{array}$ & $\begin{array}{l}\text { Mean } \\
\text { (SD) }\end{array}$ & $\begin{array}{l}\text { Mean } \\
\text { (SD) }\end{array}$ & $\begin{array}{l}\text { Mean } \\
\text { (SD) }\end{array}$ \\
\hline $\begin{array}{l}\text { The course curriculum } \\
\text { is hectic }\end{array}$ & $\begin{array}{l}3.1 \\
(1.1)\end{array}$ & $\begin{array}{l}3.2 \\
(1.1)\end{array}$ & $\begin{array}{l}3.5 \\
(1.2)\end{array}$ & $\begin{array}{l}3.5 \\
(1.1)\end{array}$ & $\begin{array}{l}3.3 \\
(1.1)\end{array}$ & $\begin{array}{l}3.3 \\
(1.1)\end{array}$ & $\begin{array}{l}3.2 \\
(1.2)\end{array}$ & $\begin{array}{l}3.6 \\
(1.1)\end{array}$ & $\begin{array}{l}3.3 \\
(1.1)\end{array}$ & $\begin{array}{l}3.4 \\
(1.2)\end{array}$ \\
\hline $\begin{array}{l}\text { The facility counseling } \\
\text { should be available }\end{array}$ & $\begin{array}{l}3.4 \\
(1.4)\end{array}$ & $\begin{array}{l}3.8 \\
(1.1)\end{array}$ & $\begin{array}{l}3.9 \\
(1.1)\end{array}$ & $\begin{array}{l}3.8 \\
(1.1)\end{array}$ & $\begin{array}{l}3.9 \\
(1.1)\end{array}$ & $\begin{array}{l}3.5 \\
(1.2)\end{array}$ & $\begin{array}{l}3.9 \\
(1.1)\end{array}$ & $\begin{array}{l}4.0 \\
(1.1)\end{array}$ & $\begin{array}{l}3.8 \\
(1.1)\end{array}$ & $\begin{array}{l}3.8 \\
(1.2)\end{array}$ \\
\hline $\begin{array}{l}\text { I do prefer teachers as } \\
\text { my counselor }\end{array}$ & $\begin{array}{l}3.3 \\
(1.4)\end{array}$ & $\begin{array}{l}3.2 \\
(1.3)\end{array}$ & $\begin{array}{l}3.4 \\
(1.3)\end{array}$ & $\begin{array}{l}3.2 \\
(1.3)\end{array}$ & $\begin{array}{l}3.4 \\
(1.3)\end{array}$ & $\begin{array}{l}3.2 \\
(1.4)\end{array}$ & $\begin{array}{l}3.2 \\
(1.3)\end{array}$ & $\begin{array}{l}3.6 \\
(1.2)\end{array}$ & $\begin{array}{l}3.4 \\
(1.3)\end{array}$ & $\begin{array}{l}3.1 \\
(1.3)\end{array}$ \\
\hline $\begin{array}{l}\text { The hostel } \\
\text { accommodation is up } \\
\text { to the mark }\end{array}$ & $\begin{array}{l}2.5 \\
(1.6)\end{array}$ & $\begin{array}{l}2.7 \\
(1.3)\end{array}$ & $\begin{array}{l}2.6 \\
(1.2)\end{array}$ & $\begin{array}{l}2.8 \\
(1.3)\end{array}$ & $\begin{array}{l}2.5 \\
(1.3)\end{array}$ & $\begin{array}{l}2.3 \\
(1.5)\end{array}$ & $\begin{array}{l}2.9 \\
(1.3)\end{array}$ & $\begin{array}{l}2.6 \\
(1.1)\end{array}$ & $\begin{array}{l}2.5 \\
(1.3)\end{array}$ & $\begin{array}{l}2.9 \\
(1.3)\end{array}$ \\
\hline $\begin{array}{l}\text { I get enough quality } \\
\text { foods in college } \\
\text { campus }\end{array}$ & $\begin{array}{l}1.8 \\
(1.3)\end{array}$ & $\begin{array}{l}1.5 \\
(0.9)\end{array}$ & $\begin{array}{l}1.7 \\
(1.0)\end{array}$ & $\begin{array}{l}1.4 \\
(1.0)\end{array}$ & $\begin{array}{l}1.7 \\
(1.0)\end{array}$ & $\begin{array}{l}1.5 \\
(1.4)\end{array}$ & $\begin{array}{l}1.7 \\
(1.0)\end{array}$ & $\begin{array}{l}1.6 \\
(1.0)\end{array}$ & $\begin{array}{l}1.7 \\
(1.0)\end{array}$ & $\begin{array}{l}1.5 \\
(0.9)\end{array}$ \\
\hline $\begin{array}{l}\text { I get adequate sleep } \\
\text { everyday }\end{array}$ & $\begin{array}{l}1.3 \\
(1.2)\end{array}$ & $\begin{array}{l}2.7 \\
(1.3)\end{array}$ & $\begin{array}{l}2.9 \\
(1.2)\end{array}$ & $\begin{array}{l}2.8 \\
(1.3)\end{array}$ & $\begin{array}{l}2.8 \\
(1.3)\end{array}$ & $\begin{array}{l}3.0 \\
(1.3)\end{array}$ & $\begin{array}{l}2.5 \\
(1.3)\end{array}$ & $\begin{array}{l}3.0 \\
(1.2)\end{array}$ & $\begin{array}{l}2.9 \\
(1.3)\end{array}$ & $\begin{array}{l}2.7 \\
(1.2)\end{array}$ \\
\hline $\begin{array}{l}\text { Language is one of the } \\
\text { barrier in } \\
\text { communication } \\
\text { incampus }\end{array}$ & $\begin{array}{l}1.7 \\
(1.6)\end{array}$ & $\begin{array}{l}1.8 \\
(1.2)\end{array}$ & $\begin{array}{l}1.9 \\
(1.2)\end{array}$ & $\begin{array}{l}1.7 \\
(1.2)\end{array}$ & $\begin{array}{l}1.9 \\
(1.2)\end{array}$ & $\begin{array}{l}1.5 \\
(0.9)\end{array}$ & $\begin{array}{l}2.1 \\
(1.3)\end{array}$ & $\begin{array}{l}1.8 \\
(1.1)\end{array}$ & $\begin{array}{l}1.9 \\
(1.2)\end{array}$ & $\begin{array}{l}1.8 \\
(1.2)\end{array}$ \\
\hline $\begin{array}{l}\text { I find difficulty in } \\
\text { studying in English }\end{array}$ & $\begin{array}{l}1.4 \\
(1.1)\end{array}$ & $\begin{array}{l}1.3 \\
(0.9)\end{array}$ & $\begin{array}{l}1.2 \\
(0.7)\end{array}$ & $\begin{array}{l}1.2 \\
(0.8)\end{array}$ & $\begin{array}{l}1.3 \\
(0.8)\end{array}$ & $\begin{array}{l}1.2 \\
(0.8)\end{array}$ & $\begin{array}{l}1.4 \\
(0.9)\end{array}$ & $\begin{array}{l}1.2 \\
(0.8)\end{array}$ & $\begin{array}{l}1.4 \\
(0.8)\end{array}$ & $\begin{array}{l}1.1 \\
(0.4)\end{array}$ \\
\hline $\begin{array}{l}\text { The recreation and } \\
\text { sports facilities } \\
\text { available adequate in } \\
\text { campus }\end{array}$ & $\begin{array}{l}2.4 \\
(1.2)\end{array}$ & $\begin{array}{l}2.7 \\
(1.2)\end{array}$ & $\begin{array}{l}2.7 \\
(1.2)\end{array}$ & $\begin{array}{l}2.6 \\
(1.2)\end{array}$ & $\begin{array}{l}2.6 \\
(1.2)\end{array}$ & $\begin{array}{l}2.6 \\
(1.3)\end{array}$ & $\begin{array}{l}2.6 \\
(1.2)\end{array}$ & $\begin{array}{l}2.8 \\
(1.2)\end{array}$ & $\begin{array}{l}2.7 \\
(1.2)\end{array}$ & $\begin{array}{l}2.6 \\
(1.3)\end{array}$ \\
\hline $\begin{array}{l}\text { I am happy enough } \\
\text { being in this campus }\end{array}$ & $\begin{array}{l}3.2 \\
(1.0)\end{array}$ & $\begin{array}{l}2.9 \\
(1.1)\end{array}$ & $\begin{array}{l}3.2 \\
(1.0)\end{array}$ & $\begin{array}{l}3.0 \\
(1.1)\end{array}$ & $\begin{array}{l}3.0 \\
(1.1)\end{array}$ & $\begin{array}{l}3.0 \\
(1.2)\end{array}$ & $\begin{array}{l}3.0 \\
(1.1)\end{array}$ & $\begin{array}{l}3.2 \\
(1.0)\end{array}$ & $\begin{array}{l}3.1 \\
(1.1)\end{array}$ & $\begin{array}{l}3.0 \\
(1.1)\end{array}$ \\
\hline
\end{tabular}

In individual and contextual domain, score gradually increased with increase in age groups. Resilience score were more or less similar among both the sexes. $8^{\text {th }}$ semester students were found to be more resilient in all the domains. In individual domain also, $4^{\text {th }}$ semester students had similar resilience score (4.0) like $8^{\text {th }}$ semester students. In all the domains, hostelites were more resilient compared to day boarder students (Table 2). 
Table 2: Distribution of Resilience Score on the basis of age, sex, semester, and accommodation according to CYRM scale

\begin{tabular}{|l|l|l|l|}
\hline Variables & $\begin{array}{l}\text { Individual } \\
\text { Mean(SD) }\end{array}$ & $\begin{array}{l}\text { Care giving } \\
\text { Mean(SD) }\end{array}$ & $\begin{array}{c}\text { Contextual } \\
\text { Mean (SD) }\end{array}$ \\
\hline Age (years) & & & $38.6(6.7)$ \\
\hline $18-19$ & $39.9(6.7)$ & $29.9(5.5)$ & $37.4(6.2)$ \\
\hline $20-21$ & $42.7(6.2)$ & $27.7(5.3)$ & $39.8(6.3)$ \\
\hline $22-23$ & $41.9(6.3)$ & $28.9(6.3)$ & $3.9(1.3)$ \\
\hline Sex & & & $4.0(1.2)$ \\
\hline Male & $3.9(1.1)$ & $4.0(1.2)$ & $3.9(1.2)$ \\
\hline Female & $3.9(1.1)$ & $4.2(1.1)$ & $3.9(1.3)$ \\
\hline Semester & & & $4.0(1.2)$ \\
\hline $4^{\text {th }}$ & $4.0(1.0)$ & $4.0(1.1)$ & \\
\hline $6^{\text {th }}$ & $3.8(1.7)$ & $4.0(1.2)$ & $6.8(2.3)$ \\
\hline $8^{\text {th }}$ & $4.0(1.0)$ & $4.1(1.2)$ & $6.6(2.2)$ \\
\hline Accommodation & & & $7.9(3.4)$ \\
\hline Hostelite & $11.9(3.4)$ & $6.7(2.7)$ & \\
\hline Day Boarder & $9.4(2.7)$ & & \\
\hline
\end{tabular}

All the independent variables i.e. age, sex, semester and accommodation in MANOVA model were found to be significant. Moreover, sex*age interaction, sex*semester interaction and sex ${ }^{\star}$ accommodation interaction model wasfound to be significant. Personal skills, social skills, psychological care giving, education, played much larger role in differences across the sex, age, semester, and accommodation (Table 3).

Table 3: Results of a MANOVA Testing Sex, Age, Semester, Accommodation (Cells Contain Effect Sizes)

\begin{tabular}{|c|c|c|c|c|c|c|c|c|}
\hline Dependent variables & $\operatorname{Sex}(\mathbf{S})$ & Age (A) & $\begin{array}{l}\text { Semeste } \\
\text { r(SR) }\end{array}$ & $\begin{array}{l}\text { Accommo } \\
\text { dation(AC) }\end{array}$ & $S^{\star} A$ & $\mathrm{~S}^{*} \mathrm{SR}$ & $S^{*} A C$ & $\begin{array}{l}S^{*} A^{*} S \\
R^{*} A C\end{array}$ \\
\hline Personal skills & 0.002 & $0.069^{* * *}$ & $0.027^{* * *}$ & 0.004 & 0.002 & 0.004 & 0.001 & 0 \\
\hline Peer support & 0.004 & 0.003 & 0.001 & 0.002 & 0.002 & 0.002 & 0.004 & 0 \\
\hline Social skills & $0.012^{*}$ & $0.009^{*}$ & $0.014^{*}$ & $0.033^{* * *}$ & $0.008^{*}$ & $0.001^{*}$ & $.000^{*}$ & 0.003 \\
\hline Physical care giving & $0.006^{\star *}$ & $0.054^{* * *}$ & $0.036^{\star \star}$ & $0.009^{*}$ & $0.005^{*}$ & 0.002 & $0.001^{*}$ & 0 \\
\hline $\begin{array}{l}\text { Psychological care } \\
\text { giving }\end{array}$ & $0.039^{\star * *}$ & 0.003 & 0.002 & 0.002 & 0.001 & 0.001 & 0 & 0.002 \\
\hline Spiritual & 0.003 & 0.001 & 0.004 & 0.001 & 0.003 & 0.003 & 0 & 0.001 \\
\hline Education & 0.001 & $0.062^{* *}$ & $0.059^{\star * *}$ & $0.024^{\star *}$ & $0.001^{*}$ & $0.003^{*}$ & $0.002^{*}$ & 0 \\
\hline Cultural & 0.02 & 0.004 & 0.003 & 0.001 & 0.004 & 0.004 & 0.003 & 0.002 \\
\hline
\end{tabular}

\section{DISCUSSION}

Studies have shown relatively high levels of stress, depression, suicidal thoughts among the medical undergraduates. Very little is known about the factors that encourage positive mental health, and a recent review of research on medical student distress indicated that it is important to conduct research concerning the factors that promote well-being ${ }^{[9]}$. Measuring resilience is an excellent method towards that aim and the CYRM-28 can give a credible representation of common factors concerning resilience ${ }^{[10]}$. In the present study with a male- female ratio almost equal, resilience was found to be higher in males. Similar observation was also noted by a study conducted in the University of Chicago on the same under graduate medical students ${ }^{[11]}$. Mclntosh Emily et al also found that the female students score slightly lower in resilience index than their male counterparts among the university students of UK ${ }^{[12]}$. In contrast, gender was not found to be related to resilience in the study conducted in Midwestern urban children's hospital| ${ }^{[13]}$. This difference could be explained by the fact that this study of Midwestern urban children's hospital was 
conducted among the first year Paediatric and Medicine-Paediatric residents who has completed their under graduation and in first year of their post graduation training.

In our study it was also found there was positive association with resilience and age \& semester. Higher the age and the semester of the participant more was the resilience. Here we can conclude age and semester as the same entity as age of a student increases as he/she moves to higher semester. Similar findings were also noted in a study conducted in the University of Chicago ${ }^{[11]}$. Contradictory to present findings, resilience scores did not significantly differ with age in a study among pediatric and medicinepediatric residents of Midwestern urban children's hospital ${ }^{[13]}$.

Students residing in hostels were more resilient than their fellow friends who reside in their home. This is a clear contrast from the finding in the study of Mclntosh Emily et al where students who live away from their home show lower resilience score ${ }^{[12]}$. This is due to the fact that most of the day boarders were not exactly living with their family but are sharing single rented accommodations outside the campus. So in practice they are living in similar situations away from their family like their colleagues living in hostels.

Limitation of the study: The only limitation of the study is that it has been conducted upon medical students in a single medical college setting. The study would also be more relevant if it is conducted among medical students of other medical colleges of West Bengal in order to get a holistic picture of their resilience level.

\section{Conclusion:}

Counselling and more teacher student bonding are required to propagate the resilience level of the medical students, so that increased academic pressure in higher semesters of medical school can be better tackled with the active guidance from the teacher. Students residing in hostels also need special attention to increase resilience. These interventions will make our future doctors more strong and resilient. Resilience measurement should also be further explored in medical research education and practice.

\section{Acknowledgement:}

Resilience Research Centre, Michael Ungar, School of Social Work, Dalhousie University, Halifax, Nova Scotia, CANADA, ResilienceResearch.org.

\section{AUTHORS CONTRIBUTION}

All authors contributed equally.

\section{REFERENCES}

1. Bunevicius A, Katkute A, Bunevivius R. Symptoms of anxiety and Depression in Medical Students and Humanities Students: Relationship With Big-Five Personality Dimensions and Vulnerability To Stress. Int J Soc Psychiatry 2008;54:494-501.

2. Sreeramareddy CT, Shankar PR, Binu VS, Mukhopadhyay C, Ray B, Menezes RG. Psychological morbidity, sources of stress and coping strategies among undergraduate medical students of Nepal. BMC Med Educ. 2007;7:26.

3. Shah M, Hasan S, Malik S, Sreeramareddy CT. Perceived Stress, Sources and Severity of Stress among medical undergraduates in a Pakistani Medical School. BMC Med Educ 2010;10:2.

4. Folke C, Carpenter R, Walker B, Scheffer M, Chapin T, Rockström J. Resilience Thinking: Integrating Resilience, Adaptability and Transformability. Ecology and Society 2010;15(4):20.

5. Brand F, Jax K. Focusing the Meaning(s) of Resilience: Resilience as a Descriptive Concept and a Boundary Object. Ecology and Society 2007;12(1):23.

6. Carpenter S, Walker B, Anderies JM, Abel N. From metaphor to measurement: resilience of what to what? Ecosystems 2001;4:765-781.

7. Carpenter SR, Brock WA. Adaptive Capacity and Traps. Ecology and Society 2008;13:40.

8. Berkes F, Colding J, Folke C. Navigating socialecological systems: building resilience for complexity and change. Cambridge University Press, Cambridge, UK. 2003.

9. Kjeldstadli K, Tyssen R, Finset A, Hem E, Gude T, Gronvold NT et al. Life satisfaction and resilience in medical school - a six-year longitudinal, nationwide and comparative study. BMC Med Educ 2006;6:48.

10. Ungar M, Liebenberg L. Assessing Resilience across Cultures Using Mixed-Methods: Construction of the Child and Youth Resilience Measure. Journal of Mixed Methods Research 2011;5:126-149.

11. Houpy JC, Lee WW, Woodruff JN, Pincavage AT. Medical student resilience and stressful clinical events during clinical training. Med Educ Online 2017;22:1320187.

12. McIntosh E, Shaw J. Student Resilience Exploring the positive case for resilience. 2017. Available from: http://www.unite-group.co.uk/sites/default/files/201705/student-resilience.pdf. Last accessed January 1, 2021.

13. Olson K, Kemper KJ, Mahan JD. What Factors Promote Resilience and Protect Against Burnout in First-Year Pediatric and Medicine-Pediatric Residents? J Evid Based Complementary Altern Med 2015;20:192-8.

14. Howe A, Smajdor A, Stöckl A. Towards an understanding of resilience and its relevance to medical training. Med Educ 2012;46:349-56.

15. Tempski P, Santoa IS, Mayer FB, Enns SC, Perotta B, Paro HBMS et al. Relationship among Medical Student Resilience, Educational Environment and Quality of Life. PLoS One 2015;10:e0131535 